\title{
PENGARUH PRINSIP-PRINSIP PELAYANAN SYARIAH TERHADAP KEPUASAN KONSUMEN PADA HOTEL ASRI SYARIAH KECAMATAN PANARUKAN KABUPATEN SITUBONDO
}

\author{
Nanda Hidayan Sono dan Abi Kusairi \\ nandahidayan@gmail.com \\ Universitas Ibrahimy Situbondo
}

\begin{abstract}
ABSTRAK
Dengan seiring berkembangnya ekonomi syariah di Indonesia serta didukung adanya program Halal Tourism Industry. Salah satu tuntutan yang harus dipenuhi adalah bagaimana pelaku bisnis harus bisa memenuhi tempat penginapan yang membantu kenyamanan dalam praktek ibadah termasuk juga penyediaan makanan halal, kolam renang, spa, tempat olahraga dan beberapa fasilitas lainnya. Dalam menjalankan operasioanal kegiatan dan pengembangan bisnis perhotelan berbasis syari'ah, tentu dibutuhkan pelayanan yang baik sesuai dengan prinsip-prinsip pelayanan syariah.

Penelitian ini bertujuan untuk mengetahui pengaruh prinsip-prinsip pelayanan syariah yang terdiri dari Ketuhanan (Rabbaniyyah), Etis (Akhlaqiyyah), Realistis (Al-Waqi'iyyah), Humanistis (Al-Insaniyyah) secara parsial maupun simultan terhadap kepuasan konsumen.

Metode yang digunakan dalam penelitian ini adalah metode pendekatan kuantitatif, pengambilan sampel menggunakan teknik probability sampling dengan simple random sampling yang berjumlah 67 responden. Pengumpulan data menggunakan angket (kuesioner). Analisis data diuji menggunakan uji instrumen atau prasyarat (uji validitas dan uji reliabilitas), uji asumsi klasik (uji multikolinieritas, uji autokorelasi, dan uji heteroskedastisitas), uji hipotesis (uji regresi linier sederhana, uji regresi linier berganda, uji F dan uji t) serta uji analisis koefisien determinasi $\left(r^{2}\right)$. Dari penelitian ini dapat disimpulkan bahwa: (1) Ketuhanan (Rabbaniyyah) berpengaruh dan tidak signifikan terhadap kepuasan konsumen, dibuktikan dari nilai $t_{\text {hitung }}$ sebesar $-1,128<t_{\text {tabel }}=1,997$ atau nilai sig. $t=0,264>$ 0,05. (2) Etis (Akhlaqiyyah) berpengaruh dan signifikan terhadap kepuasan
\end{abstract}


konsumen, dibuktikan dari nilai $t_{\text {hitung }}$ sebesar $8.505>t_{\text {tabel }}=1,997$ atau nilai sig.t $=0,000<0,05$. (3) Realistis (Al-Waqi'iyyah) berpengaruh dan signifikan terhadap kepuasan konsumen, dibuktikan dengan $t_{\text {hitung }}$ sebesar $6.596>t_{\text {tabel }}=1,997$ atau nilai sig. $t=0,000<0,05$. (4) Humanistis (AlInsaniyyah) berpengaruh dan signifikan terhadap kepuasan konsumen, dibuktikan dengan $t_{\text {hitung }}$ sebesar $8.908>t_{\text {tabel }}=1,997$ atau nilai sig. $t=0$, $000<0,05$. (5) Ketuhanan (Rabbaniyyah), Etis (Akhlaqiyyah), Realistis (AlWaqi'iyyah), dan Humanistis (Al-Insaniyyah) berpengaruh dan signifikan secara simultan terhadap kepuasan konsumen, dibuktikan dengan nilai $F_{\text {hitung }}=125.015>F_{\text {tabel }}=2,51$ dengan tingkat sig. $F=0,000<0,05$.

Keywords : Prinsip-prinsip Pelayanan Syariah, Kepuasan Konsumen

\section{PENDAHULUAN}

Pelayanan merupakan salah satu hal yang perlu diperhatikan dalam menjalankan sebuah perusahaan agar konsumen merasa puas dengan pelayanan yang diberikan oleh karyawan. Tuntutan yang harus dipenuhi Halal Tourism Industry adalah bagaimana pelaku bisnis harus bisa memenuhi tempat penginapan yang membantu kenyamanan dalam praktek ibadah termasuk juga penyediaan makanan halal dan dalam penyediaan fasilitas adanya pemisah fasilitas seperti kolam renang, spa dan beberapa fasilitas lainnya.

Kepuasan konsumen menentukan minat atau tidak minatnya dalam melakukan pembelian kembali terhadap produk atau pelayanan yang sama. Jika konsumen tidak puas dengan pelayanan yang diberikan maka tidak menutup kemungkinan konsumen tidak akan memilih produk atau jasa yang kita berikan dan lambat laun perusahaan tersebut akan semakin menurun kinerja dan secara otomatis akan gulung tikar. Oleh karena itu pelayanan harus dikelola dengan baik, agar mendapatkan hasil kinerja yang optimal. Sehingga konsumen yang ada merasakan nyaman dan puas dalam menginap di hotel, merasa diperhatikan dalam segala hal serta memperoleh hasil yang maksimal. Philip kotler mendifinisikan kepuasan konsumen berkaitan dengan tingkat perasaan tamu hotel setelah tamu hotel tersebut membandingkan kinerja layanan yang dirasakan dan dibandingkan dengan harapannya (Philip Kotler, 2000). Berdasarkan pengertian tersebut jelas bahwa jika kinerja layanan hotel di bawah keinginan konsumen maka hasil 
penilaian konsumen merasa kecewa, sedangkan jika kinerja sesuai dengan keinginan, maka konsumen puas dan jika kinerja melebihi keinginan maka konsumen dapat dikatakan sangat puas. Pada sisi ini ukuran kualitas pelayanan hotel yang diterima merupakan evaluasi dari tingkat komparasi dari keinginan dengan apa yang diterima, sedangkan ukuran dari kepuasan konsumen merupakan rangkuman dari hasil evaluasi terhadap layanan yang diterima.

Salah satu upaya yang harus dilakukan oleh sebuah perusahaan untuk mencapai tujuan yang diharapkan yaitu dengan meningkatkan kualitas pelayanan yang ada. Dengan meningkatkan kualitas pelayanan, maka kepuasan konsumen akan semakin meningkat. Kepuasan konsumen akan tercapai dengan baik apabila perusahaan mampu memberikan pelayanan kerja terhadap konsumennya (Widyarini, 2013).

Salah satu usaha untuk meningkatkan kepuasan kerja karyawan, diantaranya adalah dengan memperhatikan prinsip-prinsip pelayanan syariah (Widyarini, 2013). Prinsip-prinsip pelayanan syariah adalah nilai dasar atau suatu jasa akomodasi yang menganut substansi ajaran Islam (DSNMUI, "Pedoman Penyelenggaraan Pariwisata Berdasarakan Prinsip Syariah” http://tafsirq.com/fatwa/dsn-mui/pdomanpenylenggaraanpariwisata-berdasarkan-prinsip-syariah/, diakses pada tanggal 30 Nopember 2019). Secara operasionalnya, pelayanan yang diberikan di hotel syariah tentunya hampir menyerupai hotel konvensional/non syariah pada umumnya, namun konsep hotel syariah ini lebih menyeimbangkan aspek-aspek spiritual Islam yang berlaku di dalam pengelolaan dan pengoperasiannya.

Hal ini senada dengan Vinna Sri Yuniarti pada buku berjudul "Perilaku Konsumen teori dan praktik" yang menjelaskan Segala bentuk pelayanan yang dilakukan oleh Hotel Syariah tujuannya untuk memberikan kebutuhan, keinginan dan harapan bagi konsumen (Vinna Sri Yuniarti, 2017).

Hotel Asri Syariah Situbondo merupakan Hotel syariah satu-satunya yang ada di Kabupaten Situbondo berlokasi di Jl. Raya Panarukan Rt. 01 Rw. 02 Desa Wringin Anom Kecamatan Panarukan Kabupaten Situbondo. di daerah kota santri dengan menyasar wisatawan muslim yang berkunjung di Situbondo. Selain itu, Hotel Asri Syariah Situbondo hadir di tengah Kota untuk mendukung wisatawan yang ingin menikmati wisata yang ada di Situbondo. 
Pelayanan secara syariah yang diterapkan oleh karyawan dalam melayani para konsumen dilakukan dengan penuh tanggung jawab, dan melayani para konsumen dengan baik serta menjelaskan mengenai fasilitas yang dimiliki oleh hotel dengan jujur dan penuh dengan tatak rama yang baik, serta dalam melayani karyawan melayani dengan penunjang fasilitas seperti menyediakan kelengkapan sholat dan menjaga kesucian kamar hotel, serta karyawan cekatan dan sigap menanggapi permasalahan dan keluhan para konsumen yang dirasakan ketika menerima pelayanan yang tidak sesuai dengan prinsip-prinsip pelayanan syariah.

Penelitian ini bertujuan untuk menjelaskan pengaruh prinsip-prinsip pelayanan syariah yang teridir dari Ketuhanan (Rabbaniyyah), Etis (Akhlaqiyyah), Realistis (Al-Waqi'iyyah), Humanistis (Al-Insaniyyah) secara parsial maupun simultan terhadap kepuasan konsumen di Hotel Asri Syariah Situbondo.

\section{KAJIAN TEORI}

\section{Prinsip-prinsip Pelayanan Syariah}

Dalam Kamus Besar Bahasa Indonesia (KBBI), prinsip adalah asas (kebenaran yg menjadi pokok dasar berpikir, bertindak) atau dasar yang berdasarkan kepada Al-qur'an dan As-Sunah yang mencakup sekumpulan aturan-aturan dan prinsip-prinsip yang jika dijalankan akan menghasilkan kesuksesan besar bagi para pelaku bisnis, baik di dunia maupun di akhirat. Prinsip syariah yang diterapkan dalam bisnis perhotelan menurut Dewan Syariah Nasional Majelis Ulama' Indonesia (DSNMUI) antara lain sebagai berikut:

1. Hotel syariah tidak boleh menyediakan fasilitas akses pornografi dan tindakan asusila.

2. Hotel syariah tidak boleh menyediakan fasilitas hiburan yang mengarah pada kemusyrikan dan maksiat.

3. Makanan dan minuman yang disediakan hotel syariah tidak boleh mengandung bahan yang haram, seperti daging babi dan alkohol.

4. Menyediakan fasilitas, peralatan dan sarana yang memadai untuk pelaksanaan ibadah, termasuk fasilitas bersuci.

5. Pengelolaan dan karyawan/karyawati wajib mengenakan pakaian yang sesuai dengan syariah.

Adapun salah satu dasar dari hukum hotel berbasis syariah dapat dilihat pada ayatayat yang dinukil dalam Al-Qur'an berikut ini: 


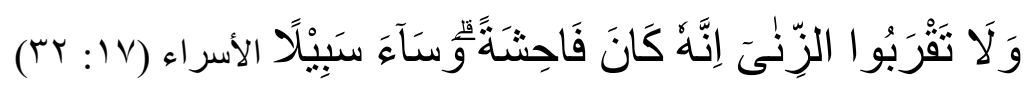

Artinya: Dan janganlah kamu mendekati zina; Sesungguhnya zina itu adalah suatu perbuatan yang keji, dan suatu jalan yang buruk". (QS. Al-Israa', (17): 32).

Berdasarkan QS. Al-Israa' ayat 32 dan Al-Mu'minun ayat 7 tersebut menunjukan bahwa zina merupakan perbuatan yang keji, sehingga hukumnya haram untuk dilakukan. Manajemen hotel berbasis syariah, sebagai penyedia jasa penginapan berkewajiban untuk melarang terjadinya zina untuk para tamunya.

Para pelaku bisnis syari'ah harus berpedoman pada aturan yang sudah Allah tetapkan tersebut baik dalam bentuk perintah maupun larangan. Sedangkan pelayanan syariah adalah Menurut Fandy Tjiptono, pelayanan dalam Bahasa Arab dikenal dalam istilah Khidmah dan pelayanan tersebut merupakan jiwa dalam bisnis syariah. Al-quran memerintahkan dengan sangat ekspresif agar kaum muslim bersifat lembut dan sopan santun manakala berbicara dan melayani pelanggan (Fandy Tjiptono, 2004). Hal ini ditegaskan dalam Al-quran Surat Ali Imran ayat 159 :

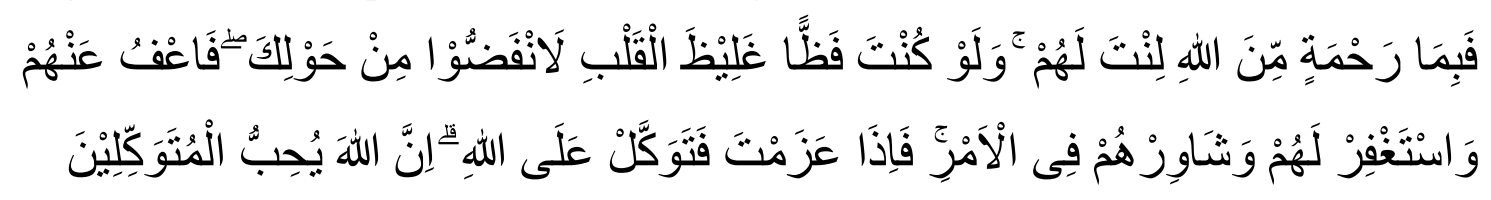

Artinya: Maka disebabkan rahmat dari Allah-lah kamu Berlaku lemah lembut terhadap mereka. Sekiranya kamu bersikap keras lagi berhati kasar, tentulah mereka menjauhkan diri dari sekelilingmu. karena itu ma'afkanlah mereka, mohonkanlah ampun bagi mereka, dan bermusyawaratlah dengan mereka dalam urusan itu[246]. kemudian apabila kamu telah membulatkan tekad, Maka bertawakkallah kepada Allah. Sesungguhnya Allah menyukai orang-orang yang bertawakkal kepada-Nya.

Pada ayat tersebut, mengajarkan manusia agar bersikap lemah lembut kepada saudaranya baik dalam hal berbicara dan bersikap, sebagai teladan umat, nabi Muhammad SAW sudah mempraktekkan dalam bermuamalah atau berbisnis. Beliau dikenal sebagai Al-Amin (orang yang dipercaya) dan Ash-Shiddiq (orang yang benar dan jujur) sehingga tidak sekalipun bisnis yang ditangani beliau mendapat kerugian, karena beliau menerapkan prinsip-prinsip pelayanan sesuai dengan syariah. 
Berdasarkan beberapa pendapat mengenai Prinsip-prinsip Pelayanan Syariah tersebut, maka dapat disimpulkan bahwa Prinsip-prinsip Pelayanan Syariah merupakan segala bentuk tindakan atau khidmah atau jasa yang diberikan oleh perusahaan kepada para konsumen sesuai dengan Al-qur'an dan As-sunnah. Pelayanan yang baik adalah yang mampu melayani konsumen agar puas dan nyaman atas jasa yang kita berikan kepada konsumen sehingga konsumen tidak segan untuk kembali datang ke hotel untuk menginap lagi. Dan perusahaan akan mengalami kemajuan yang signifikan.

Tujuan dengan adanya penerapan prinsip-prinsip pelayanan syariah ini yaitu agar kepuasan karyawan tercapai. Kepuasan karyawan akan tercapai dapat dilihat dari beberapa kondisi. Salah satunya yaitu pelayanan yang karyawan adalah menepati janji atau tidak ingkar dalam melayani konsumen. Hal ini senada dengan yang dijelaskan oleh Vinna Sri Yuniarti, tujuan tujuannya untuk memberikan kebutuhan, keinginan dan harapan bagi konsumen (Vinna Sri Yuniarti, 2017).

Adapun indikator prinsip-prinsip pelayanan syariah dalam penelitian ini, yaitu: Ketuhanan atau teitis (rabbaniyyah), etis (akhlaqiyyah), realistis (al-waqi'iyyah), dan humanistis (al-insaniyyah) (Hermawan Kertajaya dan Muhammad Syakir Sula, 2006).

\section{Kepuasan Konsumen}

Menurut Philip Kotler dikutip oleh Vinna Sri Yuniarti dalam bukunya berjudul "Perilaku Konsumen" bahwa kepuasan konsumen merupakan sejauh mana suatu tingkatan produk dipersiapkan sesuai dengan harapan pembeli. Kepuasan konsumen diartikan sebagai keadaan dimana harapan konsumen terhadap suatu produk sesuai dengan kenyataan yang diterima oleh konsumen.

Kepuasan konsumen diukur dari seberapa besar harapan konsumen tentang produk, harga dan pelayanan sesuai dengan kinerja produk, harga dan pelayanan yang aktual. Secara umum, kepuasan diartikan sebagai adanya kesamaan antara kinerja produk dan pelayanan yang diterima dengan kinerja produk dan pelayanan yang diharapkan konsumen.

Kepuasan nasabah adalah evaluasi setelah pembelian (purnabeli, di mana alternatif yang dipilih paling tidak memberikan hasil (outcome) sama atau melampaui harapan pelanggan, sedangkan ketidak puasan dapat timbul jika hasil yang diperoleh tidak memenuhi harapan pelanggan (Fandy Tjiptono, 2004). 
Menurut Kotler dan Amstrong dalam yang dikutip oleh Fandi Tjiptono dalam bukunya berjudul Manajemen Jasa bahwa harapan lampau, opini teman, dan kerabat serta informasi dan janji-janji perusahaan dan para pesaing. Dalam praktek bisnis bahwa harapan seseorang selalu berkaitan dengan konsumen dibentuk dan didasarkan oleh beberapa faktor di antaranya pengalaman berbelanja dimasa lima hal berikut ini:

a. Ketidaksesuaian antara harapan aktual dengan ide yang diterima akan menjadi pengalaman yang tidak menyenangkan, dan ini akan hilang ketika nasabah memperoleh produk lain yang memenuhi identitas diri mereka.

b. Konsumen cenderung akan menggunakan jasa yang dipersepsikan memiliki kesesuaian citra produk dengan persepsi dan harapan yang diinginkannya.

c. Perilaku konsumen dipengaruhi oleh jenis usaha atau aktivitas mereka dan konsistensi harapan terhadap citra dan kualitas kinerja produk dan layanan yang dipersepsikan.

d. Pelayanan yang baik menghasilkan kepuasan, menciptakanhubungan yang harmonis dan silaturahmi yang lancar.

e. Produk yang dirasakan cocok dan pelayanan yang diterima menyenangkan, nasabah akan mengendalikan faktor eksternal yang merusak citra perusahaan yang digunakan.

Berdasarkan beberapa pendapat diatas dapat disimpulkan kepuasan konsumen adalah sikap konsumen pada saat dan setelah memakai atau membeli produk atau jasa dan puas atau tidak puasnya akan ditentukan setelah menggunakan produk atau jasa tersebut. Apabila konsumen merasa puas, maka konsumen akan memilih kembali jasa tersebut. Tetapi, apabila kepuasan konsumen tidak tercapai atau kurang baik, maka akan menyebabkan perusahaan kehilangan konsumen dan pemasukan perusahaan akan menurun (Abi Kusairi, "Pengaruh Prinsip-Prinsip Pelayanan Syariah Terhadap Kepuasan Konsumen Pada Hotel Asri Syariah Kecamatan Panarukan Kabupaten Situbondo", (SkripsiUniversitas Ibrahimy, Situbondo, 2020,10.). Maka ada beberapa indikator dan dimensi menurut Zeithaml dan Bitner yang dikutip oleh Tjiptono pada bukunya yang berjudul "Manajemen Jasa" yaitu: Tangible (Bukti Langsung/Berwujud), Reliability (Kehandalan), Responsiveness (Daya Tanggap), Assurance (Jaminan), Emphaty (Empati).

\section{Hipotesis}

Hipotesis pada dasarnya merupakan suatu proporsi untuk anggaran yang mungkin besar dan sering digunakan sebagai dasar pembuatan keputusan atau pemecahan 
persoalan ataupun dasar penelitian lebih lanjut (Sugiyono ). Hipotesis adalah jawaban sementara atas pertanyaan penelitian yang dalam hal ini terdapat di dalam rumusan masalah.

Adapun hipotesis sebagaimana berikut:

a. Ketuhanan (Rabbaniyah) berpengaruh signifikan terhadap kepuasan konsumen hotel Asri Syariah Situbondo.

b. Etis (Akhlaqiyyah) berpengaruh signifikan terhadap kepuasan konsumen hotel Asri Syariah Situbondo.

c. Realistis (Al-Waqi'iyyah) berpengaruh signifikan terhadap kepuasan kepuasan konsumen hotel Asri Syariah Situbondo.

d. Humanistis (Al-insyaniyyah) berpengaruh signifikan terhadap kepuasan kepuasan konsumen hotel Asri Syariah Situbondo.

e. Ketuhanan, etis, realistis, dan humanistis secara bersama-sama berpengaruh signifikan terhadap kepuasan kepuasan konsumen hotel Asri Syariah Situbondo.

\section{METODE PENELITIAN}

Jenis penelitian ini menggunakan penelitian kuantitatif. Penelitian kuantitatif adalah penelitian survey yang berlandaskan pada filsafat positivisme digunakan untuk meneliti pada populasi atau sampel tertentu, pengumpulan data menggunakan instrumen penelitian, analisis data bersifat kuantitaif/statistik dengan tujuan untuk menggambarkan dan menguji hipotesis yang telah ditetapkan (Sugiyono ). Populasi dalam penelitian ini adalah 80 konsumen Hotel Asri Syariah Situbondo. Sampel dalam penelitian ini sebanyak 67 konsumen Hotel Asri Syariah Situbondo dengan tingkat kesalahan 5\% (Sugiyono ). Teknik analisis data yang digunakan yaitu:

1. Analisis Deskriptif

Analisis ini digunakan untuk mendeskripsikan karakteristik penelitian dengan menggambarkan obyek yang terdiri dari keadaan responden yang diteliti, lokasi penelitian, serta item-item yang didistribusikan dari setiap variabel. Setelah seluruh data terkumpul, selanjutnya mengolah data yang diperoleh dari responden dan mentabulasikan ke dalam tabel, kemudian membahas data yang telah diolah tersebut secara deskriptif. Pengukuran deskriptif yang dimaksud dengan memberikan angka, baik dalam jumlah atau pun persentase.

2. Analisis Regresi berganda 
Analisis regresi berganda adalah suatu teknik analisis yang digunakan untuk mengetahui hubungan searah (kausalitas/pengaruh) antara dua atau lebih variabel independen dengan variabel dependen serta untuk melakukan prediksi/peramalan (predicting/forcasting) terhadap nilai variabel dependen didasarkan atas nilai pada variabel independennya.

\section{HASIL DAN PEMBAHASAN}

\section{Analisis Regresi Berganda}

Analisis regresi berganda adalah analisis yang digunakan untuk mengetahui pengaruh secara linier antara dua atau lebih variabel independen dengan variabel dependen. Dalam penelitian ini dapat dilihat seberapa besar pengaruh variabel bebas, yaitu Variabel Ketuhanan (Rabbaniyyah) $\left(\mathrm{X}_{1}\right)$, Etis (Akhlaqiyyah) $\left(\mathrm{X}_{2}\right)$, Realistis (AlWaqi'iyyah) $\left(\mathrm{X}_{3}\right)$, dan Humanistis (Al-Insaniyyah) $\left(\mathrm{X}_{4}\right)$ dan Secara bersamaan manajemen pemasaran syariah $\left(\mathrm{X}_{5}\right)$ berpengaruh terhadap variabel terikat, yaitu kepuasan konsumen (Y). Berikut ini adalah hasil dari perhitungan regresi linier berganda yang ditampilkan dalam bentuk tabel.

Tabel 1: Hasil Perhitungan Regresi Berganda

Coefficients $^{\mathbf{a}}$

\begin{tabular}{|l|l|l|l|l|l|}
\hline \multirow{2}{*}{ Model } & \multicolumn{2}{|l|}{$\begin{array}{l}\text { Standardize } \\
\text { Unstandardized } \\
\text { Coefficients }\end{array}$} & $\begin{array}{l}\text { d } \\
\text { Coefficients }\end{array}$ & \\
\cline { 2 - 4 } & $\mathrm{B}$ & Std. Error & Beta & $\mathrm{t}$ & Sig. \\
\hline 1 (Constant) & 5.643 & 3.206 & & 1.760 & .083 \\
Ketuhanan & -.197 & .175 & -.056 & -1.128 & .264 \\
Etis & 1.475 & .173 & .425 & 8.505 & .000 \\
Realistis & 1.350 & .205 & .346 & 6.596 & .000 \\
Humanistis & 1.743 & .196 & .476 & 8.908 & .000 \\
\hline
\end{tabular}

a. Dependent Variable: Kepuasan Kerja

Dari tabel di atas dapat dirumuskan regresi linier berganda dengan persamaan sebagai berikut :

$\mathrm{Y}=\mathbf{5 , 6 4 3}+\mathbf{0 , - 0 5 6} \mathrm{X} 1+0,425 \mathrm{X} 2+0,346 \mathrm{X3}+0,476 \mathrm{X} 4+\mathrm{e}$ 
Keterangan: Y adalah Kepuasan Konsumen, X1 adalah teistis (Rabbaniyyah), X2 adalah Etis (Akhlaqiyyah), X3 adalah Realistis (Al-Waqi'iyyah), X4 adalah Humanistis (Al-insaniyyah) dan e adalah error. Dari persamaan di atas, dapat dianalisis beberapa hal diantaranya adalah sebagai berikut:

a. Nilai konstanta pada persamaan tersebut sebesar 5,643. Ini artinya bahwa apabila empat variabel Ketuhanan (Rabbaniyyah), Etis (Akhlaqiyyah), Realistis (AlWaqi'iyyah), dan Humanistis (Al-insaniyyah) dianggap konstan maka nilai dari kepuasan konsumen adalah 5,643.

b. Koefisien regresi untuk variabel teistis (Rabbaniyyah) (X1) sebesar -0,056 bermakna bahwa jika terjadi peningkatan pada variabel motivasi sebesar 100\% maka akan terjadi peningkatan juga pada kepuasan konsumen sebesar $-5,6 \%$ dengan asumsi variabel teistis (Rabbaniyyah) tidak mengalami perubahan. Koefisien bernilai negatif artinya tidak terjadi hubungan positif antara teistis (Rabbaniyyah) dengan kepuasan konsumen. Semakin negatif teistis (Rabbaniyyah) maka semakin tidak puas konsumen.

c. Koefisien regresi untuk variabel Etis (Akhlaqiyyah) (X2) sebesar 0,425 bermakna bahwa jika terjadi peningkatan pada variabel lingkungan kerja sebesar 100\% maka akan terjadi peningkatan juga pada kepuasan konsumen sebesar 42,5\% dengan asumsi variabel Etis (Akhlaqiyyah) tidak mengalami perubahan. Koefisien bernilai positif artinya terjadi hubungan positif antara Etis (Akhlaqiyyah) dengan kepuasan konsumen. Semakin baik Etis (Akhlaqiyyah) maka semakin meningkat kepuasan konsumen.

d. Koefisien regresi untuk variabel Realistis (Al-Waqi'iyyah) (X3) sebesar 0,346 bermakna bahwa jika terjadi peningkatan pada variabel lingkungan kerja sebesar $100 \%$ maka akan terjadi peningkatan juga pada kepuasan konsumen sebesar $34,6 \%$ dengan asumsi variabel Realistis (Al-Waqi'iyyah) tidak mengalami perubahan. Koefisien bernilai positif artinya terjadi hubungan positif antara Etis (Akhlaqiyyah) dengan kepuasan konsumen. Semakin baik Realistis (Al-Waqi'iyyah) maka semakin meningkat kepuasan konsumen.

e. Koefisien regresi untuk variabel Humanistis (Al-insaniyyah) (X4) sebesar 0,476 bermakna bahwa jika terjadi peningkatan pada variabel lingkungan kerja sebesar $100 \%$ maka akan terjadi peningkatan juga pada kepuasan konsumen sebesar 
47,6\% dengan asumsi variabel Humanistis (Al-insaniyyah) tidak mengalami perubahan. Koefisien bernilai positif artinya terjadi hubungan positif antara Humanistis (Al-insaniyyah) dengan kepuasan konsumen. Semakin baik Humanistis (Al-insaniyyah) maka semakin meningkat kepuasan konsumen.

Tabel 2: Koefisien Korelasi dan Koefisien Determinasi

Model Summary

\begin{tabular}{|l|r|r|r|r|}
\hline Model & \multicolumn{1}{|c|}{$\mathrm{R}$} & R Square & \multicolumn{1}{|c|}{$\begin{array}{c}\text { Adjusted R } \\
\text { Square }\end{array}$} & \multicolumn{1}{|c|}{$\begin{array}{c}\text { Std. Error of the } \\
\text { Estimate }\end{array}$} \\
\hline 1 & $.943^{\mathrm{a}}$ & .890 & .883 & 1.125 \\
\hline
\end{tabular}

a. Predictors: (Constant), Humanistis, Ketuhanan, Etis, Realistis

Berdasarkan Tabel 2 diatas, nilai koefisien korelasi adalah sebesar 0,943. Hal ini menunjukkan bahwa terdapat hubungan yang kuat antara variabel motivasi kerja dan lingkungan kerja terhadap kepuasan konsumen sebesar 94,3\%. Sehingga dapat dinyatakan terdapat hubungan yang positif antara variabel Ketuhanan, Etis, Realistis, dan Humanistis terhadap kepuasan konsumen yang dikategorikan kuat. Selain itu, dapat diketahui nilai koefisien determinasi (Adjusted Rsquare) sebesar 0,883. Artinya bahwa variabel Ketuhanan/Rabbaniyyah (X1), Etis/Akhlaqiyyah (X2), Realistis/Al-waqi'iyah (X3), dan Humanistis/Al-insaniyyah (X4) dapat mempengaruhi terhadap variabel Kepuasan Konsumen (Y) sebesar 88,3\%, sedangkan sisanya 11,7\% dipengaruhi oleh variabel lain yang tidak dibahas dalam penelitian.

\section{Pengujian Hipotesis}

\section{a. Uji Hipotesis 1}

Uji hipotesis 1 yang berbunyi bahwa variable variabel ketuhanan/rabbaniyyah $\left(\mathrm{X}_{1}\right)$ berpengaruh terhadap variabel kepuasan konsumen (Y) dapat dibuktikan dengan menggunakan uji-t. Hasil analisis uji-t dapat diketahui bahwa nilai $t_{\text {hitung }}$ variabel ketuhanan/rabbaniyyah $\left(\mathrm{X}_{1}\right)$ adalah $-1,128<t_{\text {tabel }}=$ 1,997 atau nilai sig. $\mathrm{t}=0,264>0,05$, maka $H_{0}$ diterima dan $H_{1}$ ditolak. Artinya ketuhanan/rabbaniyyah $\left(X_{1}\right)$ tidak berpengaruh signifikan secara parsial terhadap kepuasan konsumen (Y). Atau hipotesis penelitian yang diajukan yaitu pengaruh signifikan ketuhanan/rabbaniyyah terhadap kepuasan konsumen studi kasus hotel Asri Syariah Situbondo tidak dapat dipenuhi. 


\section{b. Uji hipotesis 2}

Uji hipotesis 2 yang berbunyi bahwa variabel etis/akhlaqiyyah $\left(\mathrm{X}_{2}\right)$ berpengaruh terhadap variabel kepuasan konsumen (Y) dapat dibuktikan dengan menggunakan uji-t. Hasil analisis uji-t dapat diketahui bahwa nilai $t_{\text {hitung }}$ variabel etis/akhlaqiyyah $X_{2}$ adalah 8,505 $>t_{\text {tabel }}=1,997$ atau nilai sig. $\mathrm{t}=0,000<0,05$, maka $H_{0}$ ditolak dan $H_{1}$ diterima. Artinya etis/akhlaqiyyah $\left(\mathrm{X}_{2}\right)$ berpengaruh signifikan secara parsial terhadap kepuasan konsumen (Y). Atau hipotesis penelitian yang diajukan yaitu pengaruh signifikan etis/akhlaqiyyah terhadap kepuasan konsumen studi kasus hotel Asri Syariah Situbondo dapat dipenuhi.

\section{c. Uji Hipotesis 3}

Uji hipotesis 3 yang berbunyi bahwa variabel realistis/al-waqi'iyyah $\left(\mathrm{X}_{3}\right)$ berpengaruh terhadap variabel kepuasan konsumen (Y) dapat dibuktikan dengan menggunakan uji-t. Hasil analisis uji-t dapat diketahui bahwa nilai $t_{\text {hitung }}$ variabel realistis/al-waqi'iyyah $\left(\mathrm{X}_{3}\right)$ adalah 6,596 $>t_{\text {tabel }}=1,997$ atau nilai sig. $\mathrm{t}=0,000<$ 0,05, maka $H_{0}$ ditolak dan $H_{1}$ diterima. Artinya realistis/al-waqi'iyyah $\left(X_{3}\right)$ berpengaruh signifikan secara parsial terhadap kepuasan konsumen (Y). Atau hipotesis penelitian yang diajukan yaitu pengaruh signifikan realistis/al-waqi'iyyah terhadap kepuasan konsumen studi kasus hotel Asri Syariah Situbondo dapat dipenuhi.

\section{d. Uji Hipotesis 4}

Uji hipotesis 4 yang berbunyi bahwa variabel humanistis/al-insaniyyah $\left(\mathrm{X}_{4}\right)$ berpengaruh terhadap variabel kepuasan konsumen (Y) dapat dibuktikan dengan menggunakan uji-t. Hasil analisis uji-t dapat diketahui bahwa nilai $t_{\text {hitung }}$ variabel humanistis/al-insaniyyah $\left(\mathrm{X}_{4}\right)$ adalah 8,908 $>t_{\text {tabel }}=1,997$ atau nilai sig. $\mathrm{t}=0,000$ $<0,05$, maka $H_{0}$ ditolak dan $H_{1}$ diterima. Artinya humanistis/al-insaniyyah $\left(X_{4}\right)$ berpengaruh signifikan secara parsial terhadap kepuasan konsumen (Y). Atau hipotesis penelitian yang diajukan yaitu pengaruh signifikan realistis/al-waqi'iyyah terhadap kepuasan konsumen studi kasus hotel Asri Syariah Situbondo dapat dipenuhi.

\section{e. Uji Hipotesis 5}

Uji hipotesis 5 yang berbunyi bahwa Ketuhanan/Rabbaniyyah (X1), Etis/Akhlaqiyyah (X2), Realistis/Al-waqi'iyyah (X3), dan Humanistis/Al-insaniyyah 
(X4) berpengaruh secara simultan terhadap variabel kepuasan konsumen (Y) dapat dibuktikan dengan menggunakan uji-F.

\section{Tabel 3: Hasil Uji-F}

\begin{tabular}{|c|c|c|c|c|c|}
\hline \multicolumn{6}{|c|}{ ANOVA $^{b}$} \\
\hline Model & $\begin{array}{l}\text { Sum of } \\
\text { Squares }\end{array}$ & Df & $\begin{array}{l}\text { Mean } \\
\text { Square }\end{array}$ & $\mathrm{F}$ & Sig. \\
\hline 1 Regression & 633.142 & 4 & 158.285 & 125.015 & $.000^{\mathrm{a}}$ \\
\hline Residual & 78.500 & 62 & 1.266 & & \\
\hline Total & 711.642 & 66 & & & \\
\hline
\end{tabular}

Hasil analisis uji-F diperoleh nilai signifikan $F_{\text {hitung }}=125,015$ dengan tingkat sig. $\mathrm{F}=0,000$, karena nilai $F_{\text {hitung }}=125,015>F_{\text {tabel }}=2,51$ dan nilai sig. $\mathrm{F}=0.000<$ 0,05 maka $H_{0}$ ditolak dan $\mathrm{H}_{-} 1$ diterima. Artinya terdapat pengaruh yang signifikan ketuhanan/rabbaniyyah (X1), etis/akhlaqiyyah (X2), realistis/al-waqi'iyyah (X3) dan humanistis/al-insaniyyah (X4) secara simultan terhadap kepuasan konsumen (Y) studi kasus hotel Asri Syariah Situbondo. Dengan demikian model regresi dapat digunakan untuk memprediksi variabel kepuasan konsumen.

\section{PEMBAHASAN}

\section{Pengaruh Nilai Ketuhanan (Rabbaniyyah) Terhadap Kepuasan Konsumen.}

Berdasarkan hasil analisis data bahwa ketuhanan/rabbaniyyah tidak berpengaruh positif dan signifikan terhadap kepuasan konsumen, dimana nilai $t_{\text {hitung }}=-1,128<t_{\text {tabel }}$ $=1,997$ atau nilai sig. $\mathrm{t}=0,264>0,05$, sehingga $H_{0}$ diterima dan $H_{1}$ ditolak. Berdasarkan uji hipotesis dapat diketahui bahwa ketuhanan/rabbaniyyah tidak berpengaruh secara signifikan terhadap kepuasan konsumen. Karena nilai $t_{\text {hitung }}$ lebih besar dari $t_{\text {tabel }}$. Sehingga dapat disimpulkan bahwa variabel ketuhanan/rabbaniyyah tidak berpengaruh positif dan signifikan terhadap kepuasan konsumen.

Hal ini disebabkan karena konsumen hotel Asri Syariah Situbondo merasa bahwa dengan tersedianya berbagai macam prouk yang ditawarkan akan memudahkan dalam memilih sesuai dengan kebutuhan dan keinginannya. 
Hal tersebut juga didukung oleh penelitian sebelumnya yang berjudul "Pengaruh Penerapan Karakteristik Marketing Syariah Terhadap Kepuasan Nasabah Pada Bank Syariah Sragen" oleh Elly Mery Irawati (2016) menyatakan bahwa dalam penelitian tidak terdapat pengaruh ketuhanan/religius terhadap kepuasan konsumen. (Elly Mery Irawati, "Pengaruh Penerapan Karakteristik Marketing Syariah Terhadap Kepuasan Nasabah Pada Bank Syariah Sragen”, Skripsi IAIN Salatiga, Salatiga, 2016). Dalam penelitian tersebut, marketer tidak terlalu mementingkan nilai ketuhanan atau religiusitas dalam bekerja tetapi lebih mengutamakan tanggung jawabnya sebagai marketing yaitu memasarkan hotel terhadap konsumen.

\section{Pengaruh Nilai Etis (Akhlaqiyyah) Terhadap Kepuasan Konsumen.}

Berdasarkan hasil analisis data bahwa etis/akhlaqiyyah berpengaruh terhadap kepuasan konsumen, dimana nilai $t_{\text {hitung }}=8,505>t_{\text {tabel }}=1,997$ atau nilai sig.t $=0,000$ $<0,05$, sehingga $H_{1}$ diterima dan $H_{0}$ ditolak. Berdasarkan uji hipotesis dapat diketahui bahwa etis/akhlaqiyyah berpengaruh secara signifikan terhadap kepuasan konsumen. Karena nilai $t_{\text {hitung }}$ lebih besar dari $t_{\text {tabel }}$. Sehingga dapat disimpulkan bahwa etis/akhlaqiyyah hotel Asri Syariah Situbondo berperilaku secara sopan, santun dan ramah serta menyambut para konsumen dengan ucapan salam, sehingga konsumen merasa diperlakukan sebagai seorang raja, konsumen merasa bersahaja dan konsumen merasa puasa akan pelayanan yang diberikan marketer hotel Asri Syariah.

Hal tersebut juga didukung dan selaras dengan penelitian sebelumnya yang berjudul "Pengaruh Karakteristik Syariah Marketing Terhadap Kepuasan Konsumen Studi Kasus di Duta Mode Purwokerto" oleh Kristiana (2016) menyatakan bahwa terdapat pengaruh nilai etis/akhlaqiyyah terhadap kepuasan konsumen di Duta Mode Purwokerto.

Menurut Ratih, pelayanan prima adalah perilaku yang memainkan peranan dalam penyajian jasa sehingga dapat mempengaruhi dan rasa kepuasan pembeli (Hurriyati dan Ratih, 2005). Sedangkan menurut pendapat Fandy Tjiptono Pelayanan mempunyai pengaruh besar terhadap perusahaan dalam menarik para konsumennya (Fandy Tjiptono, 2004).

\section{Pengaruh Nilai Realistis (Al-waqi'iyyah) Terhadap Kepuasan Konsumen.}

Berdasarkan hasil analisis data bahwa realistis/al-waqi'iyyah berpengaruh terhadap kepuasan konsumen, dimana nilai $t_{\text {hitung }}=6,596>t_{\text {tabel }}=1,997$ atau nilai sig.t 
$=0,000<0,05$, sehingga $H_{1}$ diterima dan $H_{0}$ ditolak. Berdasarkan uji hipotesis dapat diketahui bahwa realistis/ al-waqi'iyyah berpengaruh secara signifikan terhadap kepuasan konsumen. Karena nilai $t_{\text {hitung }}$ lebih besar dari $t_{\text {tabel }}$. Sehingga dapat disimpulkan bahwa nilai realistis/al-waqi'iyyah hotel Asri Syariah Situbondo memberikan pelayanan secara cekatan, teliti dan tepat dalam bertindak, tidak hanya itu marketer dalam pelayanannya berpenampilan bersih, rapi serta santun sehingga menghasilkan kepuasan para konsumen.

Hal tersebut juga didukung dan selaras dengan penelitian sebelumnya yang berjudul "Pengaruh Karakteristik Syariah Marketing Terhadap Kepuasan Konsumen Studi Kasus di Duta Mode Purwokerto" oleh Kristiana (2016) menyatakan bahwa terdapat pengaruh nilai etis/akhlaqiyyah terhadap kepuasan konsumen di Duta Mode Purwokerto.

Menurut Kartajaya dan Syakir sula menjelaskan bahwa Realistis (fleksibel) marketer harus profesional, santun dan rapi dalam penampilan serta tidak kaku dalam pergaulan sehingga konsumen merasa puas akan pelayanan yang diberikan.

Pada penelitian ini, peneliti menemukan fakta yang mengarah pada hubungan yang kuat atau bisa dikatakan tinggi mengenai variabel realistis (al-waqi 'iyyah) terhadap kepuasan konsumen pada hotel Asri Syariah Situbondo. Hal ini ditunjukkan oleh nilai koefisien korelasi dan determinasi yang tinggi.

\section{Pengaruh Nilai Humanistis (Al-Insaniyyah) Terhadap Kepuasan Konsumen.}

Berdasarkan hasil analisis data bahwa humanistis/al-insaniyyah berpengaruh terhadap kepuasan konsumen, dimana nilai $t_{\text {hitung }}=8,908>t_{\text {tabel }}=1,997$ atau nilai sig. $\mathrm{t}=0,000<0,05$, sehingga $H_{1}$ diterima dan $H_{0}$ ditolak. Berdasarkan uji hipotesis dapat diketahui bahwa humanistis/al-insaniyyah berpengaruh secara signifikan terhadap kepuasan konsumen. Karena nilai $t_{\text {hitung }}$ lebih besar dari $t_{\text {tabel }}$. Sehingga dapat disimpulkan bahwa humanistis/al-insaniyyah hotel Asri Syariah Situbondo menghasilkan pelayanan yang baik, marketer dalam hal ini membantu kesulitan yang konsumen dan mau mendengarkan keluhan yang dirasakan konsumen sehingga dapat memuaskan para konsumen.

Hal tersebut juga didukung dan selaras dengan penelitian sebelumnya yang berjudul "Pengaruh Karakteristik Syariah Marketing Terhadap Kepuasan Konsumen Studi Kasus di Duta Mode Purwokerto" oleh Kristiana (2016) menyatakan bahwa 
terdapat pengaruh nilai etis/akhlaqiyyah terhadap kepuasan konsumen di Duta Mode Purwokerto.

Menurut Kartajaya dan Syakir Sula menjelaskan bahwa Humanistis (manusiawi) artinya seorang marketer harus menjaga keseimbangan, mmiliki harkat dan derajat terhormat dan memelihara sifat kemanusiaannya, menghilangkan nafsu kehewanan, tidak serakah, melainkan peduli pada keadaan sosial.

Pada penelitian ini, peneliti menemukan fakta yang mengarah pada hubungan yang kuat atau bisa dikatakan tinggi mengenai variabel humanistis (al-insaniyyah) terhadap kepuasan konsumen pada hotel Asri Syariah Situbondo. Hal ini ditunjukkan oleh nilai koefisien korelasi dan determinasi yang tinggi.

Besar Pengaruh ketuhanan (rabbaniyyah), etis (akhlaqiyyah), relistis (al-waqi'iyyah) dan humanistis (al-insaniyyah) secara simultan terhadap kepuasan konsumen.

Berdasarkan hasil analisis yang diketahui nilai koefisien $\mathrm{R}^{2}$ hitung (Koefisien Determinasi), yakni sebesar 0,890. Hasil ini menunjukkan bahwa kontribusi variabel bebas mempengaruhi variabel terikat sebesar 89,0\%. Hasil tersebut dapat disimpulkan bahwa kemampuan variabel independen $(\mathrm{X})$ untuk menjelaskan varians pada variabel dependen (Y) adalah sebesar 89,0\%, selebihnya, yaitu 11,0\% dijelaskan oleh faktor lain yang tidak dijelaskan dalam model regresi yang diperoleh dan uji $\mathrm{F}$ yang menghasilkan $F_{\text {hitung }}=125,015$ dengan tingkat signifikan sebesar 0,000 .

Sesuai fakta yang ada, besar pengaruh variabel persepsi bagi hasil hanya sebesar 89,0\% terhadap variabel kepuasan konsumen. Hal ini berarti ketuhanan (rabbaniyyah), etis (akhlaqiyyah), relistis (al-waqi'iyyah) dan humanistis (al-insaniyyah) artinya terdapat pengaruh yang signifikan secara simultan terhadap kepuasan konsumen Hotel Asri Syariah Situbondo.

\section{KESIMPULAN}

Berdasarkan hasil penelitian yang telah dibahas, maka dapat kita Tarik kesimpulan sebagai berikut:

1. Berdasarkan hasil analisis data bahwa ketuhanan/rabbaniyyah berpengaruh dan tidak signifikan terhadap kepuasan konsumen, dimana nilai $t_{\text {hitung }}=-1,128<t_{\text {tabel }}=$ 
1,997 atau nilai sig. $\mathrm{t}=0,264>0,05$, sehingga $H_{0}$ diterima dan $H_{1}$ ditolak. Karena nilai $t_{\text {hitung }}$ lebih kecil dari $t_{\text {tabel }}$.

2. Berdasarkan hasil analisis data bahwa etis/akhlaqiyyah berpengaruh dan signifikan terhadap kepuasan konsumen, dimana nilai $t_{\text {hitung }}=8,505>t_{\text {tabel }}=1,997$ atau nilai sig.t $=0,000<0,05$, sehingga $H_{1}$ diterima dan $H_{0}$ ditolak. Karena nilai $t_{\text {hitung }}$ lebih besar dari $t_{\text {tabel }}$.

3. Berdasarkan hasil analisis data bahwa realistis/al-waqi'iyyah berpengaruh dan signifikan terhadap kepuasan konsumen, dimana nilai $t_{\text {hitung }}=6,596>t_{\text {tabel }}=1,997$ atau nilai sig. $\mathrm{t}=0,000<0,05$, sehingga $H_{1}$ diterima dan $H_{0}$ ditolak. Karena nilai $t_{\text {hitung }}$ lebih besar dari $t_{\text {tabel }}$.

4. Berdasarkan hasil analisis data bahwa humanistis/al-insaniyyah berpengaruh dan signifikan terhadap kepuasan konsumen, dimana nilai $t_{\text {hitung }}=8,908>t_{\text {tabel }}=1,997$ atau nilai sig. $\mathrm{t}=0,000<0,05$, sehingga $H_{1}$ diterima dan $H_{0}$ ditolak. Karena nilai $t_{\text {hitung }}$ lebih besar dari $t_{\text {tabel }}$.

5. Berdasarkan hasil analisis data bahwa ketuhanan/rabbaniyyah, etis/akhlaqiyyah, realistis/al-waqi'iyyah, humanistis/al-insaniyyah bahwa nilai $F_{\text {hitung }}=125,015$ dengan tingkat sig. $\mathrm{F}=0,000$, karena nilai $F_{\text {hitung }}=125,015>F_{\text {tabel }}=2,51$ dan nilai sig. $F=0.000<0,05$ Artinya terdapat pengaruh yang signifikan secara simultan terhadap kepuasan konsumen. Sedangkan nilai koefisien $r^{2}$ hitung (Koefisien Determinasi), yaitu sebesar 89,0\%. Besaran ini menunjukkan pada efektivitas garis regresi yang diperoleh dalam menjelaskan varians pada variabel independen. Hasil tersebut dapat disimpulkan bahwa kemampuan variabel independen $(\mathrm{X})$ untuk menjelaskan varians pada variabel dependen (Y) adalah sebesar 89,0\%. Selebihnya, yaitu 11,0\% dijelaskan oleh faktor lain yang tidak dijelaskan dalam model regresi yang diperoleh.

\section{DAFTAR PUSATAKA}

Alma, Buchari. Manajemen Pemasaran dan Pemasaran Jasa. Bandung: ALFABETA, 2011.

Asri, Marwan. Marketing. Yogyakarta: UPP-AMP YKNPN, 1991.

Assauri, Sofyan, Manajemen Pemasaran. Jakarta: PT Raja Grafindo Persada, 2011. 
Augusty. Metode penelitian manajemen pedoman penelitian untuk penulisan skripsi, tesis, dan disertasi. Dipenogoro: Badan penerbit UNDIP, 2014.

Dinas Pariwisata, "Dispar tahun kunjungan wisatawan dikutip dari http://disparsitubondo.go.id/konten/, diakses pada tanggal 4 Desember 2019.

DSNMUI, "Pedoman Penyelenggaraan Pariwisata Berdasarakan Prinsip Syariah" http://tafsirq.com/fatwa/dsn-mui/pdomanpenylenggaraan-pariwisata-

berdasarkan-prinsip-syariah/, diakses pada tanggal 30 Nopember 2019.

Harini, Sri. Hasil Wawancara. Situbondo: 28 Agustus 2018.

Hasan, Ali. Manajemen Bisnis Syariah. Yogyakarta: Pustaka Pelajar, 2009.

Hurriyati, Ratih. Bauran Pemasaran dan Loyalitas Konsumen. Jakarta: Erlangga, 2005.

Irawati, Mery, Elly. "Pengaruh Penerapan Karakteristik Marketing Syariah Terhadap Kepuasan Nasabah Pada Bank Syariah Sragen”. Skripsi - IAIN Salatiga, 2016.

Kepuasan Pelanggan Perspektif Islam, http://www.dakwatuna.com /2007/hukum-islam, diakses pada tanggal 30 Mei 2020.

Kertajaya, Hermawan. Sula, Syakir, Muhammad. Syariah Marketing. Bandung: Mizan Pustaka, 2006.

Kotler dan Armstrong, Prinsip - Prinsip Pemasaran Jilid 1 Edisi kedelapan. Jakarta: Erlangga, 2001.

Kotler, Philip. Manajemen Pemasaran. Indonesia: PT Macanan Jaya Cemerlang, 2002.

Kotler, Philip. Marketing Management, Edisi Milenium. Prentice Hall Intl, Inc New Jersey, 2000.

Kuncoro, Mudraj. Metode Kuantitatif. Yogyakarta: Unit Penerbit dan Percetakan Sekolah Tinggi Ilmu Manajemen YKPN, 2001.

Manullang, M. Dasar-Dasar Manajemen. Jakarta: Balai Aksara, 1963.

Maswar, dkk. Analisis Korelasi dan Regresi untuk Penelitian Pendidikan, Ekonomi dan Bisnis dilengkapi dengan Penggunaan SPSS 23 dan Eviews 8.1. Surabaya: Pustaka Raja, 2017.

Moekiyat. Kamus Management. Bandung: Alumni, 1980.

Mudhafier, Fadhlan. Makanan Halal. Jakarta: Zakia Press, 2004.

Nawawi, Imam. Metode Penelitian Fiqh dan Ekonomi Syari'ah. Malang: Madani media Intrans Publishing, 2019. 
Qhardawi, Yusuf. Norma dan Etika Ekonomi Islam Terjemah Zainal Arifin (et.al). Jakarta: Gema Insani Press, 1997.

Riva'i, Veithzal. Islamic Marketing Membangun dan Mengembangkan Bisnis dengan Praktik Marketing Rasulullah SAW. Jakarta: PT.Gramedia Pustaka Utama, 2012.

Rivai, Vaithzal dkk. Islamic Business and Economic Ethics. Jakarta: PT Bumi Aksara, 2011. 